\title{
Conversion of Cellulosic waste into fermentable sugar: Process optimization
}

\author{
Salam M. A. ${ }^{1}$, Paritush Chandra Pondith ${ }^{1}$, Ariful Islam ${ }^{1}$, Maksudur Rahman Khan ${ }^{1,2}$, \\ Mohammad Rakib Uddin ${ }^{1}$, and Islam M. A. ${ }^{1}$ \\ ${ }^{I}$ Department of Chemical Engineering and Polymer Science; Shahjalal University of Science and Technology \\ (SUST); Sylhet 3114, Bangladesh; Email: salam_ceps@yahoo.com \\ ${ }^{2}$ Faculty of Chemical and Natural Resources Engineering, University Malaysia Pahang, 26300 Gambang, Kuantan, \\ Pahang, Malaysia
}

\begin{abstract}
Fossil fuel is depleting day by day throughout the world. This limitation along with the problem of Green House Gas (GHG) emissions leads findings for alternative energy that are environmentally and commercially feasible. Every day we are dumping lot of cellulosic waste materials into the environment from which we can produce valuable product such as ethanol to trim down the energy demand on fossil fuel. In the present study waste paper was treated to produce fermentable sugar using both conventional and enzymatic process. Acid catalyzed hydrolysis is conducted using sulfuric acid and the enzymatic process utilized municipal drain sludge. For acid catalyzed process optimum glucose concentration was found around $4 \mathrm{mg} / \mathrm{ml}$ for a loading of $1.5 \mathrm{~g}$ of untreated waste paper in $100 \mathrm{ml}$ working volume at $25 \pm 2^{\circ} \mathrm{C}$ and a $\mathrm{P}^{\mathrm{H}}$ of 5 in about $1.5 \mathrm{hrs}$ of hydrolysis. In case of enzymatic hydrolysis glucose yield was found around $2.5 \mathrm{mg} / \mathrm{L}$ for $10 \mathrm{ml}$ sludge dosing in $100 \mathrm{ml}$ working volume at $30^{\circ} \mathrm{C} \pm 2$ and $\mathrm{P}^{\mathrm{H}}$ of 7 in about 1.15 hrs of operation. In addition, base catalyzed hydrolysis is also observed with $5 \% \mathrm{NaOH}$ and results around $3.3 \mathrm{mg} / \mathrm{ml}$ of glucose at room temperature and a $\mathrm{P}^{\mathrm{H}}$ of 13.0 in $1.5 \mathrm{hrs}$ of hydrolysis.
\end{abstract}

\section{INTRODUCTION}

Lignocellulosic materials such as agricultural (e.g., sugar cane bagasse) and forest residues (e.g., saw dust), municipal solid waste (e.g., waste paper) woody crops and herbaceous (e.g., switch grass) materials in large quantities are available in many countries with various climatic conditions, making them suitable and potentially cheap feedstock for sustainable production of fuel ethanol. Such materials are abundant and competitive in price with petroleum, and cellulosic biomass can provide a sustainable resource that is truly unique for making organic products [1]. In addition such materials provide a new pathway to manufacture organic fuels and chemicals which can be useful in part of world where there is a shortage of petroleum resources. However, the majority of the total carbohydrates in biomass are presented in forms of lignocelluloses like cellulose, hemicellulose or lignin.

Generally structural part of the cellulosic biomass is a composite of cellulosic chains joined together by hydrogen bonding. These long cellulose fibers are in turn held together with hemicellulose and lignin, allowing growth to large aerial plants that can withstand weather and attack by microorganisms and insects. Usually, humans have employed cellulosic biomass for such uses as construction, soil stabilization, animal feed, and paper manufacture. However, the cellulose and hemicellulose portions of biomass, representing about $40-50 \%$ and $20-30 \%$ by dry weight of plants, respectively, are

*Corresponding Author: MA Salam

E-mail: $\underline{\text { salam_ceps@yahoo.com }}$ polysaccharides that can be broken down into sugars and fermented or chemically altered to valuable fuels and chemicals. Wayman et al reported biological conversion of cellulosic biomass to the point of becoming economically competitive for production of fuels and chemicals that offer important strategic, environmental, and economic advantage [2]. Conversion of lignocellulosic material to fermentable sugar is therefore an important step in the production of bioethanol

In our everyday life we are dumping lot of papers as a solid waste which creates environmental problem. We could use it as solid fuel that can provide us a maximum calorific value of approximately $16 \mathrm{MJ} / \mathrm{Kg}$ [3]. But if we can convert it into ethanol, i.e. liquid fuels, it calorific value can be as high as $30 \mathrm{MJ} / \mathrm{Kg}$ [4] which have diverse functionalities. Wayman M. et al. reported ethanol yields of 350-400 liters/t of wastepaper, at $8 \%$ ethanol by volume [5]. Lark N. et al. reported 32 and $35 \mathrm{~g} / \mathrm{l}$ of ethanol from 180 and $190 \mathrm{~g} / \mathrm{l}$ dry recycled paper sludge [6].

The first step in the production of bioethanol is the hydrolysis of cellulosic materials into fermentable sugars. The hydrolysis of lignocelluloses materials is more difficult than the hydrolysis of storage polysaccharides like starch. The hemicelluloses fraction is readily hydrolyzed to pentoses (five carbon sugars) but pentoses are difficult to ferment [7]. The cellulose exists as both amorphous and crystalline forms, which hydrolyze to hexoses (six carbon sugars). Crystalline cellulose is recalcitrant to 
hydrolysis. However, the resulting hexoses are readily fermented. There are normally two ways to hydrolyze cellulose: chemically and enzymatically. Chemical method uses strong acids whereas enzymatic process utilized variety of microorganisms. Different substances are used in the cellulose hydrolysis process such as Sulfuric acid, Hydrochloric acid, heterogeneous solid acids, sulfonated carbonaceous based acids, polymer based acids and magnetic solid acids [8]

In the present work a comparative study of acid hydrolysis and enzymatic hydrolysis were studied. Both processes are optimized in terms of reaction conditions. In addition base hydrolysis is introduced as an alternative competitive of the above process. Aim of the present study is to find out economically and commercially feasible hydrolysis process for the conversation of cellulosic waste into fermentable sugars.

\section{MATERIAL AND METHODS}

\subsection{Collection and Preparation of Feedstocks}

Waste paper collected from local areas of Surma Residential Area and Student Hostel of Shahjalal University of Science and Technology of Sylhet (SUST), Bangladesh was directly used to make paper slurry with distilled water in a batch container. Slurry of different waste paper loading was prepared for the hydrolysis steps.

\subsection{Study of acid hydrolysis}

In the acid catalyzed hydrolysis step $20 \%$ concentrated $\mathrm{H}_{2} \mathrm{SO}_{4}$ was used as the reagent. Different amount of paper slurry was treated at different $\mathrm{P}^{\mathrm{H}}$ and different temperature of the reaction medium. Temperature was measured by thermometer fitted with the batch reactor and $\mathrm{P}^{\mathrm{H}}$ was measured using $\mathrm{P}^{\mathrm{H}}$ meter. Heating was completed in heater. Data had been taken during different time interval to measure the concentration of glucose according to Miller [9].

\subsection{Collection and Preparation of drain sludge}

Bacterial microorganisms for hydrolysis of cellulose were collected in the form of sludge from the waste discharge point of student hostel of SUST, Sylhet. Collected sludge was filtered with the conventional filter papers and the filtrate was used for enzymatic hydrolysis.

\subsection{Study of Enzymatic Hydrolysis}

Maintaining different ratios of substrate (waste paper slurry) and bacterial sludge this process was also studied in batch process with varying reaction temperature and $\mathrm{P}^{\mathrm{H}}$.

\subsection{Study of Base Hydrolysis}

In this process $5 \% \mathrm{NaOH}$ was employed to waste slurry at a $\mathrm{pH}$ of around 13.0 and the hydrolysis data are recorded and compared with the two other processes.

\section{RESULTS AND DISCUSSIONS}

\subsection{Effect of $\mathbf{P}^{\mathrm{H}}$ on acid hydrolysis}

Acid hydrolysis largely depends on the concentration of the acid solution used as shown in Fig. 1. Breakage of the $\beta$-1, 4-glycosidic bonds by acids leads to the hydrolysis of cellulose polymers, resulting in the sugar molecule glucose or oligosaccharides. A $\mathrm{P}^{\mathrm{H}}$ of 5 can yield a glucose concentration of about $4.0 \mathrm{mg} / \mathrm{ml}$ in about $1.5 \mathrm{hrs}$ whereas $\mathrm{P}^{\mathrm{H}}$ of 4 and 6 can yield glucose as high as $3.75 \mathrm{mg} / \mathrm{ml}$ in $1 \mathrm{hr}$ intervals.

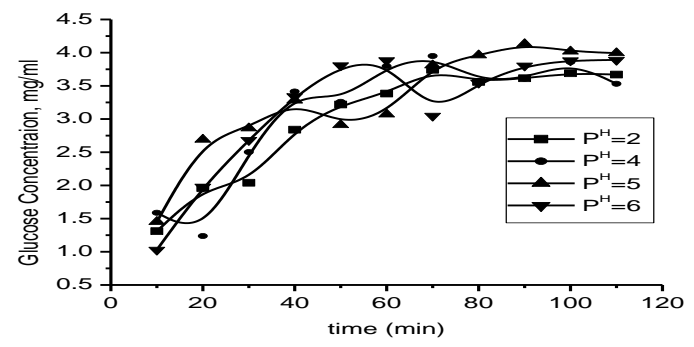

Fig. 1: Effect of $\mathrm{P}^{\mathrm{H}}$ on the conversion of waste paper to glucose by acid hydrolysis

\subsection{Effect of waste paper loading on the yield of glucose production}

Fig. 2 represents that $4.5 \mathrm{~g}$ of waste paper in $300 \mathrm{ml}$ of waste slurry can yield as much as $4.0 \mathrm{mg} / \mathrm{ml}$ of glucose just after 80 minutes of hydrolysis.

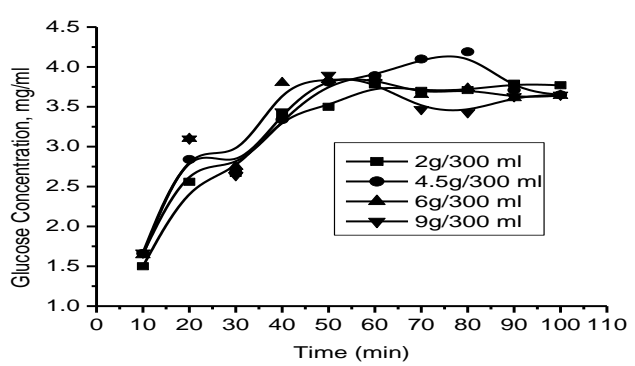

Fig. 2: Effect of waste paper loading on the yield of 
glucose at a $\mathrm{P}^{\mathrm{H}}$ of 5 and with $20 \%$ concentrated $\mathrm{H}_{2} \mathrm{SO}_{4}$

Zehui Zhang et al. reported a novel method for cellulose hydrolysis catalyzed by mineral acids and mentioned a glucose yield of $39.2 \%$ in $1.0 \mathrm{~g}$ $\mathrm{NMP} / 3.0 \mathrm{~g}$ [Bmim] $\mathrm{Cl}$ system at $70{ }^{\circ} \mathrm{C}$ [10]. In the present study loading of waste paper at $4.5 \mathrm{~g} / 300 \mathrm{ml}$ lead to almost $28 \%$ yield of glucose at about $25 \pm 2^{\circ} \mathrm{C}$.

\subsection{Temperature effect on acid hydrolysis}

Room temperature $\left(25^{\circ} \mathrm{C}\right)$ is effective for acid hydrolysis with $20 \%$ acid concentration at a $\mathrm{P}^{\mathrm{H}}$ of 5.0. A. Orozco et al. reported $90 \%$ yield of glucose using $2.5 \%$ phosphoric acid at a temperature of $175^{\circ} \mathrm{C}$. [11]

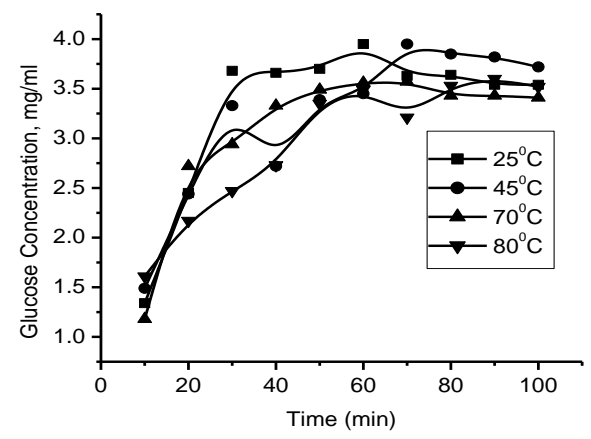

Fig. 3: Effect of temperature on acid hydrolysis at $\mathrm{P}^{\mathrm{H}}$ of 5

3.4 Comparative study of acid-base hydrolysis Cellulose is quite resistant to alkaline hydrolysis [12]. Under strong basic condition glycosidic linkage can be broken and leads the conversion to yield glucose. Illustration in Fig. 4 shows conversion of cellulose is more favorable for acid in terms of glucose concentration.

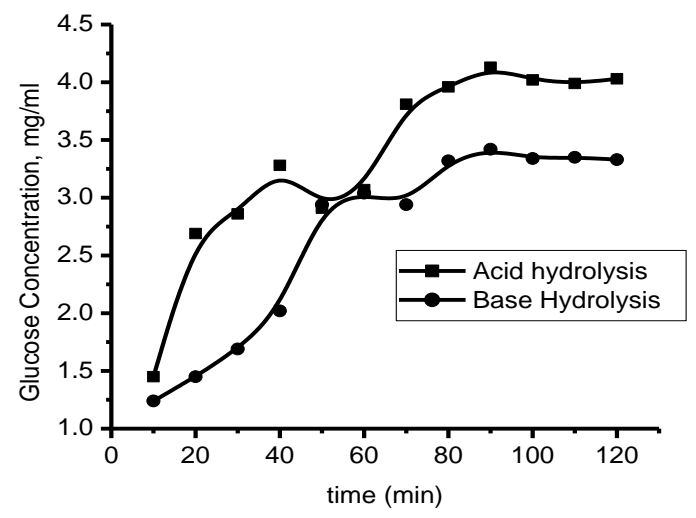

Fig. 4: Glucose concentration in acid hydrolysis and base hydrolysis (Acid: $20 \% \mathrm{H}_{2} \mathrm{SO}_{4}$, at $\mathrm{P}^{\mathrm{H}}=5$; Base: $5 \% \mathrm{NaOH}$, at $\mathrm{P}^{\mathrm{H}}=13$ )

\subsection{Study of Enzymatic hydrolysis}

Both aerobic (Fig. 5) and anaerobic (Fig.6) process shows rapid increase of glucose concentration especially in the first hour of hydrolysis followed by a reduction of the same. This may be due to shortage of cellulosic in waste or the reduction of microorganism present in the sludge due to unfavorable conditions of the reaction environment. Glucose concentration can be as high as $2.5 \mathrm{mg} / \mathrm{ml}$ in both processes for a dosing of $10 \mathrm{ml}$ drain sludge in $4.5 \mathrm{~g}$ of waste paper $/ 300 \mathrm{ml}$ of slurry.

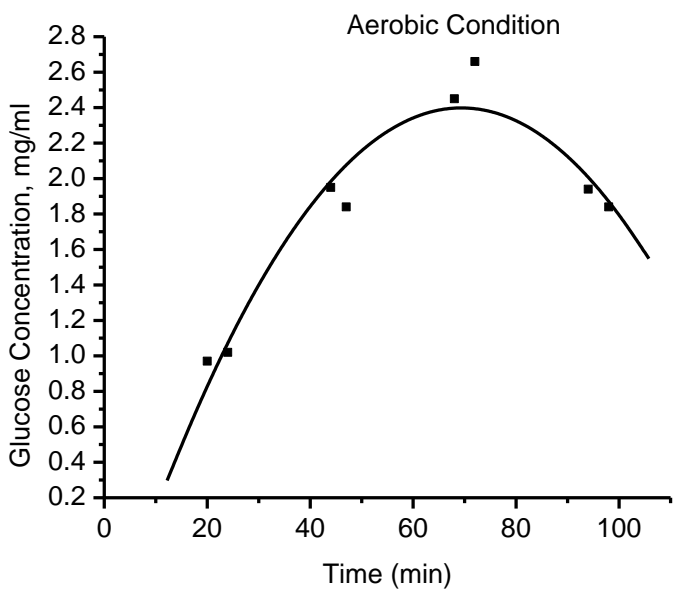

Fig. 5: Aerobic enzymatic hydrolysis by drain sludge at room temperature and at a $\mathrm{P}^{\mathrm{H}}$ close to 7 . 


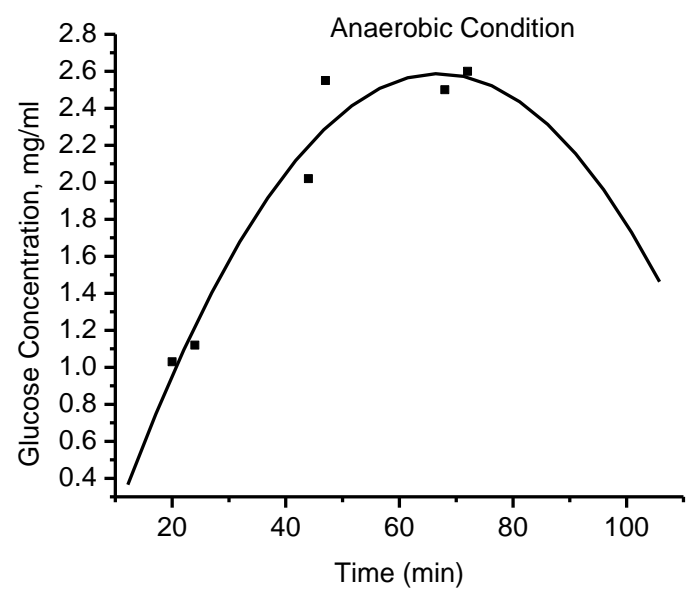

Fig. 6: Anaerobic enzymatic hydrolysis by drain sludge at room temperature and at a $\mathrm{P}^{\mathrm{H}}$ close to 7 .

P. Saha et al reported $1.4742 \mathrm{~g} / \mathrm{L}$ of glucose from rice straw at $30^{\circ} \mathrm{C}$ and a $\mathrm{P}^{\mathrm{H}}$ of $7.0[13]$

\subsection{Effect of substrate and sludge loading}

Usually in the enzymatic process increasing substrate increases the product concentration. In the present case maximum glucose yield was observed in case of $4.5 \mathrm{~g}$ of waste paper in $300 \mathrm{ml}$ of working volume as shown in Fig.7. Effect of sludge loading is shown in Fig.8.

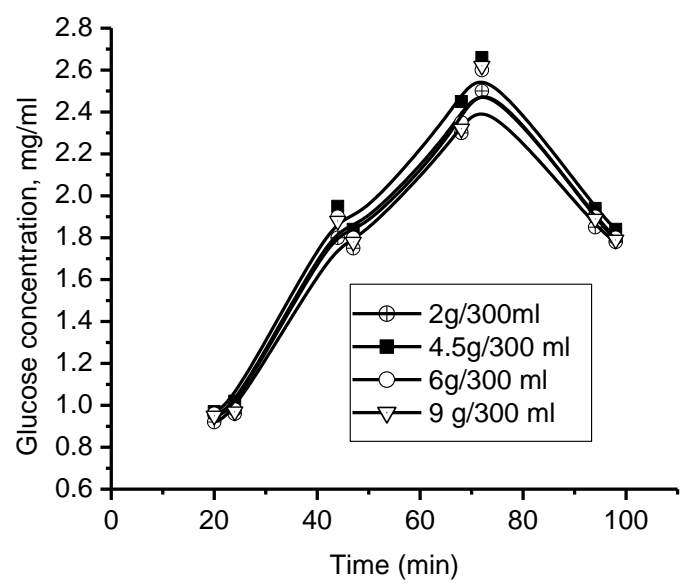

Fig. 7: Effect of initial substrate on sugar formation (Waste paper loading $4.5 \mathrm{~g} / 300 \mathrm{ml}$, sludge loading: $10 \mathrm{ml} / 100 \mathrm{ml}, \mathrm{P}^{\mathrm{H}}=7$ )

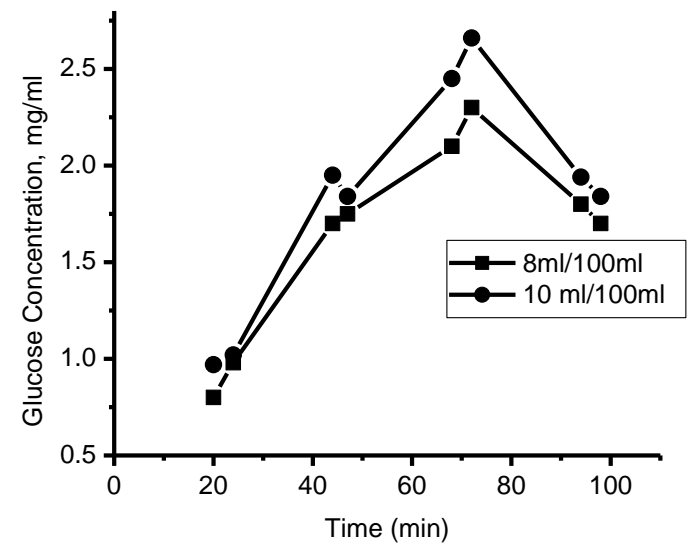

Fig. 8: Effect of sludge loading on sugar formation (Waste paper loading $4.5 \mathrm{~g} / 300 \mathrm{ml}, \mathrm{P}^{\mathrm{H}}=7$, Temperature $30^{\circ} \mathrm{C}$ )

\subsection{Effect of temperature and $\mathbf{P}^{\mathrm{H}}$ on enzymatic hydrolysis}

Optimum temperature and $\mathrm{PH}$ was found $30 \pm 2^{\circ} \mathrm{C}$ and $\mathrm{P}^{\mathrm{H}}$ of 7.0 as shown in Fig. 9 and Fig. 10.

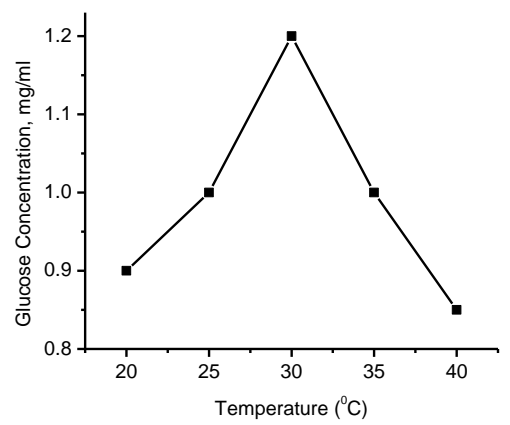

Fig. 9: Effect of temperature on sugar formation (Waste paper loading $4.5 \mathrm{~g} / 300 \mathrm{ml}$, sludge loading: $10 \mathrm{ml} / 100 \mathrm{ml}, \mathrm{P}^{\mathrm{H}}$ =7) 


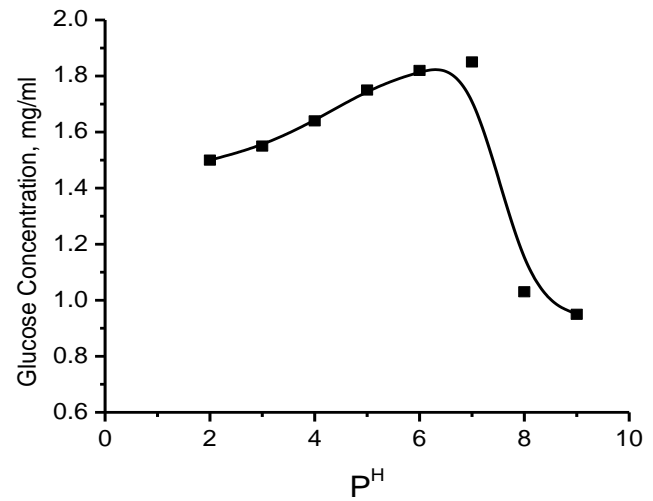

Fig. 10: Effect of $\mathrm{P}^{\mathrm{H}}$ on sugar formation (Waste paper loading $4.5 \mathrm{~g} / 300 \mathrm{ml}$, sludge loading: $10 \mathrm{ml} / 100 \mathrm{ml}$, Temperature $30^{\circ} \mathrm{C}$ )

\section{CONCLUSION}

In this study waste paper is treated in three different processes. Acid and base hydrolysis shows promising result in terms of conversion than the enzymatic process. But acid/base hydrolysis can usually suffer from the disadvantage of product separation, reactor corrosion, poor catalyst recyclability and the need for treatment of waste effluent. They can also affect the yeast or other microorganism's activity during the fermentation process. Apart from this problem enzymatic hydrolysis can play significant role. Though glucose concentration is low the process is cost effective and simple. Reaction conditions in enzymatic processes are milder than the other two processes.

\section{REFERENCES}

[1] Lynd, L.R., Cushman JH, Nichols R.J., Wyman, C.E. Fuel ethanol from cellulosic biomass, Science, 251 (1991), 1318

[2] Wyman, C.E. Biomass ethanol: Technical progress, opportunities, and commercial challenges, Annu. Rev. Energy Environ., 24 (1999), 189
[3] Gavrilescu D. Energy from biomass in pulp and paper mills, Environmental Engineering and Management Journal, 2008, Vol.7, No.5, pages 537-546

[4] http://www.winderickx.pl/en/calorific_value_of _waste.pHp, accessed on 10 November 2012

[5] Wayman M., Chen S., Doan K., Bioconversion of wastepaper to ethanol, Process Biochemistry, July 1992 Volume 27, Issue 4, , p. 239-245

[6] Lark N., Xia Y., Qin C., Gong C.S., Tsao G.T., Production of ethanol from recycled paper sludge using cellulose and yeast, Kluveromyces Marxianus, Biomass and Bioenergy, 1997, Vol. 12. No. 2, pages 135-143

[7] Sun Y, Cheng J (2002). Hydrolysis of lignocellulosic materials for ethanol Production: a review. Bioresour. Technol . 83: 1-11.

[8] Yao-Bing Huang, Yao Fu, Hydrolysis of cellulose to glucose by solid acid catalysts, Green Chem., 2013, 15, 1095-1111.

[9] Miller GL, Use of di-nitrosalicylic acid reagent for determination of reducing sugar. Anal Chem. 1959, 31, p 426-428

[10]Zehui Zhanga, Bing Liua, Zongbao (Kent) Zhao, Efficient acid-catalyzed hydrolysis of cellulose in organic electrolyte solutions, Polymer Degradation and Stability, Volume 97, Issue 4, April 2012, p. 573-577

[11] A. Orozco, M. Ahmad, D. Rooney, G. Walker, Dilute Acid Hydrolysis of Cellulose and Cellulosic Bio-Waste Using a Microwave Reactor System, Process Safety and Environmental Protection Volume 85, Issue 5, 2007, p. 446-449.

[12] Gordon I. Kaye, PH.D, Peter B. Weber, PH. D, William M. Wetzel, The Alkaline Hydrolysis Process, ALN Waste Management, September/October 2004.

[13]Pradip Saha, M.R. Khan, T.K. Deb, S. Mojumdar, F. Alam, N.C. Sarkar, Enzymatic Hydrolysis of rice straw to fermentable sugar: kinetic study, Journal of Chemical Engineering, IEB, Vol. ChE 27, No. 2. December, 2012, p. 15-19. 